\title{
EUROPEAN SECURITY AND THE TERRORIST THREAT: EVOLUTIONS AND CURRENT WAYS OF MANAGING IT Georgeta CHIRLEŞAN
}

\author{
University of Piteşti, Piteşti, g.chirlesan@gie.ro
}

\begin{abstract}
The European Security Strategy "A Secure Europe in a Better World" emphasizes on the fact that security is a precondition of development and nominates terrorism as the first key threat in the list of five major threats addressed to European security. In the "EU Internal Security Strategy in Action" the terrorism is seen as second threat (after serious and organized crime) and is pointed out as a phenomenon which requires concerted European action, due to a still existent vulnerability of our societies to terrorist attacks, "Europe being both a target and a base for such terrorism".

The paper presents the evolution of the European security environment between 1990 and 2015, emphasizing the increase of the terrorist threat and the steps and actions taken in preventing and fighting against it, as well as possible solutions for managing the terrorist phenomenon. In the final part of the paper, the findings of a case study achieved through sociological questionnaire are rendered. The study envisaged to catch the counter-terrorism perspective at the level of ordinary citizens and of decision-makers and stakeholders as well.
\end{abstract}

\section{Keywords: terrorism, threat, security environment, strategy}

\section{The European security environment 1990-2015}

After the end of the Cold War, the European security environment was influenced by regional and global factors as well. Some of the most visible and impactful determinants were disintegration of communism, dismantling of Iron Curtain, expansion of democracy, tendency of power-centres to reorganize, EU enlargement but also emergence of new international organizations and consolidation of the existing ones, globalization processes, different access to resources and rapid progress of technology and sciences with direct impact on militarization and arming. From another perspective, the European security environment was shaped by EU actions to strengthen its statute as an international player and by Russian Federation's efforts of maintaining its importance and position, despite the decrease of its political and military influence after the fall of communism.

The fall of communism in the late ' 80 s and the beginning of ' $90 \mathrm{~s}$ initiated thus a profound change on security environment in Europe. New democracies have been installed in the countries liberated from communism but also new risks and challenges have occurred for them, creating instability and lack of security. In 19902000, the European security environment met a series of crises, changes and rearrangements. Religious and ethnic intolerance together with nationalism, sometimes in extreme forms, generated tension and conflicts in the Balkans and Transnistria (Transnistria and Slovenia in 1991; Croatia 1991-1995; BosniaHerzegovina 1992-1995; Kosovo 19981999; the Macedonian conflict in 2001 [1]). 
As a reaction to all these, European security and defence strengthened and became better organized. An important contribution have brought the European Council meetings in Maastricht, Amsterdam, Cologne, Helsinki and Nice, which assumed greater responsibility to EU defence and security structures. One of the EU's enlargement objectives was to extend the zone of peace, stability and prosperity on the continent. The last three enlargement waves (2004, 2007, 2013) grew EU to 28 members and proved the validity of reforms and peaceful democratic transformations [2].

EU 2nd pillar, the Common Foreign and Security Policy (CFSP) introduced by Treaty of Maastricht was the forerunner of EU common defence. The Union pursued its CFSP objectives by common strategies, joint actions and common positions [3]. A step forward in fostering security achievements represented decision on Common Security and Defence Policy (CSDP), whose aim was to strengthen EU's external ability to act through the development of civilian and military capabilities in Conflict Prevention and Crisis Management. Another distinct element of European security environment was that all EU member states were NATO members; this gave increased stability and solid security guarantee. At Lisbon Summit, in November 2010, NATO leaders endorsed a new Strategic Concept, which states that the Alliance will "engage in a process of continual reform, to streamline structures, improve working methods and maximise efficiency." In 2003, EU adopted the European Security Strategy (ESS), which describes a security environment featured by prosperity, security, stability, peace, freedom. The document established principles and set clear objectives for advancing the EU's security interests based on core values, but nevertheless it pointed on five key-threats: terrorism, proliferation of weapons of mass destruction (WMD), regional conflicts, state failure, organised crime. Five years later the "Report on the Implementation of the European Security
Strategy" showed that EU was still stable and secure, democracy and prosperity have spread, positive changes took place in Balkans and strengthened relations were enabled with Southern and Eastern partners. Yet, Europe's security was confronted with more complex risks, threats, challenges: WMD proliferation, terrorism, organised crime, cyber security, energy security, climate change [4]. Signs of a more complicated European security environment have been identified in the "Internal security strategy for the European Union", which denounce terrorism in all its forms as first main threat for EU's internal security. Besides national securities policies and strategies, the Strategy denominates as responses to terrorism and other security key challenges, the bilateral, multilateral and regional patterns of cooperation that have also been developed. Specific instruments to achieve this cooperation are threat anticipation, planning, handling the consequences, joint work, investigations and operations of security institutions, information sharing and effectiveness assessment [5]. After 9/11 terrorist attacks in 2001, the security environment evolved toward a more active emergence of terrorism both at global level and within EU: train bombings in Madrid (March 2004) killed 52 people and injured over 700 , terrorist bombings in London's subway (July 2005) killed 191 people and injured over 1.800, Charlie Hebdo shooting in Paris or terrorist attacks in Belgium, Germany (beginning of 2015). The current security landscape is also characterized by instability and conflicts at EU's Eastern border through Russia's assaults on Ukraine (including annexation of Crimea peninsula) and the escalation of war. EU leaders stressed that a new formula to deal with Putin's strategy has to be put in place, including being more active and forceful, but trying to avoid a direct confrontation with Russia.

\section{Combating the terrorist threat in Europe: steps, actions, solutions}


The international environment is much more dynamic and complex than during the Cold War. It is a fluid, sometimes inconsistent and incoherent environment; in shaping it non-state actors gain greater importance. Lack of consensus on how to globally address security allowed the expression of various groups of interests; hence not always consistent policy could be developed.

Not only EU but the whole world faces nowadays increased vulnerability due to the newest achievements in science and technology, which differentiate the actors and their chances of ensuring own security due to uneven military potential. Cyber terrorism forces the access to states' vital information and $\mathrm{EU}$ border fluidization increases the risks of trafficking in arms, people, drugs. Declining energy, global economy, pandemics, natural disasters, WMD proliferation, organized crime, nondemocratic regimes (although such regimes are increasingly fewer in Europe) and last but not least the terrorism, represent other worrying developments for European security environment.

In March 2015 security experts sounded the alarm on a very important issue: the need to strengthen cyber defence in Europe and build a more solid protection of states, a defence fortress against cyber-attacks affecting policies, industries, businesses [6]. Among various key threats to EU, terrorism remains the most important. The fight against it encompasses (a) legal framework, (b) concrete actions, (c) involved actors \& tools, (d) tangible results.

(a) Apart from Treaties on CSFP and consequently on ESDP/CSDP (i.e. Treaty of Amsterdam; Cologne European Council 1999; Treaty of Lisbon) Europe has issued specific legislation to tackle terrorism. The most important strategic documents are "EU Counter-Terrorism Strategy" (2005) which is built around four pillars prevention, protection, pursuit, response, a detailed Action Plan listing all relevant measures under the four pillars of this strategy and the "EU Counter-Terrorism
Policy: main achievements and future challenges" (2010) which accounts on the main achievements and future challenges. Other acts that consolidate the fight against terrorism are European Council's “Report on the EU Action Plan on combating terrorism" (2011) \& "Revised Strategy on Terrorist Financing” (2008), Council Decision establishing for the period 2007 to 2013 the Specific Programme "Prevention, Preparedness and Consequence Management of Terrorism and other Security related risks" (2007).

(b) Actions to combat terrorism are clearly defined in EU Counter-terrorism Strategy and the Action Plan implementing it. A complete overview of all actions was produced in 2007 and consisted of 140 different action points; another one produced in November 2009 still included 50 action points (i.e. improve control over illicit arms \& explosives in the Balkans, support the adoption of a Comprehensive Convention on Terrorism) [7].

(c) Most relevant counter-terrorism actors and tools: Joint Situation Centre (SITCEN); European Arrest Warrant; European Evidence Warrant; Joint Investigation Teams; VIS and SIS II; Financial Action Task Force (FATF); European Network of Experts on Radicalisation (ENER); European Defence Agency, Europol, Eurojust, EU Satellite Centre.

(d) As results we need to point on the number of failed and foiled terrorist attacks in EU. The latest TESAT report shows that in 2013 this number (152) decreased compared to previous years (174 in 2011, 219 in 2012). The proportion of attacks against government facilities continued to decrease. Thus, the EU strategy and Action Plan against terrorism progresses efficiently and obtains tangible results, discouraging and foiling terrorist plots [8].

\section{Case study: the vision of citizens and responsible factors on counter-terrorism}

The field research that we performed aimed at identifying among ordinary citizens, decision-makers/stakeholders the perspective on EU security in the new 
context of increased terrorist threats. Opinion and recommendations on how to manage terrorism have been also requested. The study was based on sociological questionnaires, applied face-to-face and online in January-March 2015, to a total number of 240 persons (200 citizens and 40 stakeholders) from Muntenia (Southern part of Romania). The questionnaires contained multiple-choice and open items and had a slightly different contents, adapted to target groups (citizens \& stakeholders). Main findings are rendered below.

115 citizens were females, 85 males; 23 stakeholders were males, 17 females. $82 \%$ of citizen-respondents live in urban areas, $18 \%$ in rural; $87.5 \%$ of interviewed stakeholders are from urban environment, the rest from rural areas. $74.5 \%$ of citizens graduated high school (the rest general education, VET, higher education, other types of studies). $75 \%$ of stakeholders hold university degrees, $20 \%$ high school and $5 \%$ general education. $43.5 \%$ of citizens are employed (wide-scale of professions), $37.5 \%$ students, $18 \%$ unemployed.

\section{Citizens:}

The concept of security has different meaning for citizens: existence of peace and no threat of any kind (32.5\%), status of safety and protection $(24.5 \%)$, being sheltered from any danger, feeling of confidence and peace given by the absence of danger $(24 \%)$, lack of conflict and war (18.5\%). Main information sources are TV (67.5\%), Internet (45.5\%), media (32\%).

European Security Strategy (ESS) is not so known: only $40.5 \%$ citizens responded that they know about it (41.5\% didn't know and $17.5 \%$ could not answer).

The classification of five key-threats to security (as identified by ESS) from the most important to less important one, got the results which we expected for, namely (multiple answers could be chosen): terrorism $50 \%$, organized crime $35 \%$, WMD proliferation $24 \%$, regional conflicts $18.5 \%$, failed states $14.5 \%$ (which is highly compatible with ESS ranking, except the organized crime, which in ESS appears on the last place). A worrying result concerned stability of current security environment: $41.5 \%$ see it as little stable/instable (while $27.5 \%$ could not answer) and argued with a variety of reasons, going from "due to recent terrorist attacks", "Russia's assaults on Ukraine", "the situation in Syria" to "Western states are impermissibly tolerant", "hundreds of millions of dollars invested in terrorism" or "the intolerant extremism masked by religious fanaticism".

Being asked to comment on recent terrorist attack on Charlie Hebdo the interviewees provided original and well-argued responses. We selected one, which we believe it gathers essence of all opinions: "The attack in France is a consequence of deep insults to the central figure of Islam: Prophet Muhammad. Although insults to Christianity were no less, the fact that only Islamic fundamentalists had a reaction like this shows differences between the two religions on "resistance" to scorn. Charlie Hebdo was the representative of irresponsible freedom of opinion. It is not about giving up to freedom of expression, but to give up mockery of what is most sacred in a culture. Continuing to reprint those cartoons show not only they are not able to learn from mistakes, but rather that they prefer to persevere in them. The alarm signal is: we do not live alone in the world; with us (and among us), there are some who do not accept their values to be trampled. What we do in this situation? Do we throw the world into the air to make them all as we are, OR, we adjust our speech or to be able to live together?"

Unfortunately, despite Romania's important contribution in peace-keeping missions and contribution in international security, its image in taking part in counter-terrorism has a very low profile: $56 \%$ believe it has reduced/very reduced involvement, $31.5 \%$ appreciate it as medium. Arguments were: small country; lack of: armament, mobilization, information, training, resources, governmental empowerment; reduced investments in army, military 
technology. The reason for such answers could be lack of information and awareness. More than half of the respondents $(57 \%)$ are not satisfied with the general security level provided by Romanian state and $51.5 \%$ are dissatisfied with protection against terrorism.
Most relevant recommendations on increasing EU security envisaged: borders control, monitoring groups with extremist potential, less "relaxed" immigration policy, more severe punishments, more efficient multilateralism, strengthened transatlantic cooperation.

Table 1: Citizens' trust (\%) in Romanian institutions responsible for security

\begin{tabular}{l|c|c|c|c|c}
\hline \multicolumn{1}{c|}{ Institution } & $\begin{array}{c}\text { Very } \\
\text { much }\end{array}$ & Much & $\begin{array}{c}\text { Idon't } \\
\text { know }\end{array}$ & Little & $\begin{array}{c}\text { Not } \\
\text { at all }\end{array}$ \\
\hline Romanian Presidency & 15.5 & 37.5 & 16 & 26 & 5 \\
Supreme Council of National & 11 & 37 & 21 & 18.5 & 12.5 \\
Defence & 3.5 & 23 & 18.5 & 33.5 & 20.5 \\
Romanian Government & 14 & 44.5 & 13.5 & 17.5 & 10.5 \\
Army & 9 & 36.5 & 20 & 25.5 & 9 \\
Romanian Intelligence Service & 6 & 37.5 & 20.5 & 24.5 & 10.5 \\
Foreign Intelligence Service & & & &
\end{tabular}

Involvement in the forefront on combating terrorism should belong to: Supreme Council of National Defence (38.5\%), Parliament and Government (32\% each), Army and security authorities (26\% each). $50.5 \%$ appreciated the fight against terrorism as insufficient.

The most often proposed measures, actions or strategies to counter-act terrorism in EU and in the world were: revising ESS and protection mechanisms, consolidating national capacities, unifying armies (EU army), closer cooperation, international coordination, increased negotiations and diplomacy, higher investment in equipment and military technology, more strict control, better identification of terrorist radicalization and recruitment, crisis amelioration, better judiciary assistance.

\section{Stakeholders:}

More than half of the respondents (52.5\%) are not satisfied with the general security level provided by Romanian state and 55\% are dissatisfied with the protection against terrorism. Highest threat is terrorism 55\%, followed by organized crime $47.5 \%$, WMD proliferation $42.5 \%$, regional conflicts $32.5 \%$, failed states $15 \%$. The order of keythreats is the same like the one identified by citizens. Compared to the answers of citizens, stakeholders' opinions on causes which generated Charli Hebdo attacks seemed weaker and inconsistent: Muslim religious discrimination, the wish to impose Islamic religion, the desire for world power, to make Muslim religion ridiculous, a successful diversionary manoeuvre.

The interviewees opined that EU security level could increase by: better training of military personnel, increased military presence, a more active NATO in order to get higher intimidation, a show of strengths. From their answers it is obvious that a military-oriented approach on security is still present. It is yet to be mentioned here that our interviewees do not hold responsibilities in security sector.

Almost equal shares of stakeholders found the fight against terrorism adequate (30\%) and insufficient (35\%), while one third could not answer.

We got similar distribution of the answers regarding the current cooperation among state actors: adequate (35\%), insufficient $(37.5 \%)$, could not answer $(27.5 \%)$. The roles of stakeholders and their institutions in combating terrorism relies, according to our respondents, mainly on being informed and up-to-date and informing the others, reporting to responsible authorities on any 
abnormal/suspect/unusual event or activity, being pro-active, taking correct decisions, cooperating efficiently, observing rules and procedures in force, solving vital situations in due time.

Table 2: Stakeholders' trust (\%) in Romanian institutions responsible for security

\begin{tabular}{l|c|c|c|c|c}
\hline \multicolumn{1}{c|}{ Institution } & $\begin{array}{c}\text { Very } \\
\text { much }\end{array}$ & Much & $\begin{array}{c}\text { I don't } \\
\text { know }\end{array}$ & Little & $\begin{array}{c}\text { Not at } \\
\text { all }\end{array}$ \\
\hline Romanian Presidency & 27.5 & 42.5 & 5 & 20 & 5 \\
Supreme Council of National & 15 & 37.5 & 17.5 & 30 & - \\
Defence & 10 & 20 & 12.5 & 40 & 17.5 \\
Romanian Government & 35 & 45 & 2.5 & 15 & 2.5 \\
Army & 17.5 & 40 & 15 & 12.5 & 15 \\
Romanian Intelligence Service & 15 & 32.5 & 20 & 20 & 12.5 \\
Foreign Intelligence Service & & & & & \\
\hline
\end{tabular}

\section{Conclusions}

Ensuring security has become a more and more difficult task for responsible persons and authorities of the 21 st century. Challenges, risks and threats addressed to security have diversified and took asymmetrical and non-classical forms. Terrorism strengthened and more often terrorist attacks happen. European Union is still an environment of peace, stability and security but it has to be ready for facing terrorism and other threats. In order to efficiently attain security objectives, it has developed specific policies and strategies and has created proficient structures and instruments. Yet, the success will depend on common cooperation and joint actions of all mobilized forces and resources.

The survey we performed revealed that citizens and stakeholders in Romania are not enough informed about the current Romanian and European security. Lack of knowledge could be a major reason for negative answers and predominantly pessimistic vision. Awareness should be increased and information should be spread more largely among various target groups. Stakeholders should be provided with appropriate training; dialogue with specialists and professionals should be achieved as soon as possible.

Large percentages of citizens and stakeholders do not have enough confidence in state's structures (Government, Presidency) on security issues. On the contrary, Army is perceived as the strongest security guarantor.

Stakeholders still have a rather military approach on security, which is obsolete and should be replaced by an up-to-date perspective to include cooperation, multilateralism, negotiation, diplomacy, inclusion of suitable initiatives and measures to manage asymmetrical threats. Enhancing awareness and vigilance among all citizens could contribute in consolidating the local security environment.

\section{References}

[1] Constantin Hlihor, The Post Cold War Era: Romania and the Stability in the Balkans, the vol. "Building Stability in Weak States: The Western Balkans", ISBN: 3-901328-67-X, 2002

[2] EC, Good to know about enlargement, ISBN 978-92-79-11753-4, p. 2, 2009

[3] Consolidated version of the Treaty on European Union, art. 12, p. 17

[4] Council of the EU, Report on the Implementation of the European Security Strategy: Providing Security in a Changing World, pp. 1-5, 2008 
[5] Council of the EU, Internal security strategy for the European Union: Towards a European security model, pp. 15-18, 2010

[6] European Conference on "Cyber Defence in Europe", organised in Berlin by the Latvian Ministry of Defence and the German Federal Ministry of Defence, 25-26 March 2015

[7] Communication from the Commission to the European Parliament and the Council "The EU Counter-Terrorism Policy: main achievements and future challenges", p. 2, 2010

[8] Europol, TE-SAT 2014: EU Terrorist Situation and Trend Report, p. 46, 2014 